\title{
Immune complexes and the pathogenesis of neutropenia in Felty's syndrome
}

\author{
F C BREEDVELD, ${ }^{1}$ G J M LAFEBER ${ }^{1}$ E DE VRIES, \\ J H J M VAN KRIEKEN, ${ }^{2}$ AND A CATS ${ }^{1}$
}

From the Departments of ${ }^{1}$ Rheumatology and ${ }^{2}$ Pathology, University Hospital, Leiden, The Netherlands

SUMmARY The effect of the injection of serum from patients with rheumatoid arthritis (RA) and Felty's syndrome (FS) into mice on the number of circulating polymorphonuclear cells (PMN) was studied. The number of circulating PMN dropped to $61 \%$ (range $34-98 \%$ ) of the initial counts after the injection of FS serum. This phenomenon was observed less frequently after injection of RA serum. In contrast, injection of serum from healthy controls always resulted in an immediate increase in the number of circulating PMN. No decrease in PMN counts was found after injection of FS sera pretreated with polyethylene glycol to precipitate immune complexes (IC). Gel filtration of FS sera on Sepharose 4B showed that the effect on the PMN counts in mice did not coincide with the $7 \mathrm{~S}$ peak but occurred only in fractions containing larger material. Serum fractions from FS patients that contained IC were more active in producing neutropenia than the corresponding fractions from patients with RA. Microscopic and immunohistochemical examination of the organs from mice injected with FS serum showed sequestration of PMN and deposition of human IgG, $\operatorname{IgA}$, and IgM in the vascular bed of the lungs. These results indicate that the interaction between PMN and IC of patients with FS leads to sequestration of PMN in mice and suggests that this.interaction in humans may have a role in the pathogenesis of FS.

Since Felty first described the association of rheumatoid arthritis (RA) with splenomegaly and leucopenia (mainly due to neutropenia) ${ }^{P}$ several mechanisms have been suggested for the pathogenesis of this syndrome. Although impaired granulopoietic activity has been reported, ${ }^{23}$ the products of activation of the humoral immune system may lead to shortened survival and increased sequestration of polymorphonuclear cells (PMN) in a marginated pool. ${ }^{4-6}$ Sequestration or reduced survival of PMN, or both, in patients with Felty's syndrome (FS) have been associated with an increased binding of immunoglobulins to PMN. These PMN bound immunoglobulins have been defined as autoantibodies $^{7-13}$ but were recently characterised as immune complexes (IC) bound to Fc and $\mathbb{C 3}$ receptors on the membrane. ${ }^{14-16}$ Whether this in vivo interaction of circulating PMN and IC leads to neutropenia in FS is still uncertain.

Accepted for publication 7 February 1986.

Correspondence to Dr F C Breedveld, Department of Rheumatology, University Hospital, PO Box 9600, 2300 RC Leiden, The Netherlands.
The role of IC in relation to circulating PMN has been studied in animals. Intravenous injection of IC formed in vitro in animals caused a transient neutropenia concomitantly with sequestration of PMN in the microvascular bed. ${ }^{17} 18$ These observations suggest that the low numbers of circulating PMN in FS are due to binding of IC to PMN. High levels of circulating IC have been shown, however, in the serum from many RA patients without neutropenia. The present study was designed to investigate possible differences between the sera of patients with FS and RA by measuring their effect on the number of circulating leucocytes after injection into mice.

\section{Materials and methods}

PATIENTS AND SERA

The serum samples were derived from six patients with definite RA according to the American Rheumatism Association criteria, eight patients with FS (definite RA with spontaneous sustained neutropenia below $2.0 \times 10^{9} \mathrm{PMN} / 1$ and splenomegaly), and four healthy controls (HC). Blood was 
allowed to clot at room temperature for one hour and serum was stored in $1 \mathrm{ml}$ aliquots at $-20^{\circ} \mathrm{C}$ until use. The latex fixation and Waaler-Rose tests for rheumatoid factor were positive in all patients. Bone marrow aspirate of all FS patients showed a normal cellularity with normal percentages of mature PMN and PMN precursors. Clinical data of the patients with RA and FS are given in Table 1.

FRACTIONATION OF SERA TO ISOLATE

IMMUNE COMPLEXES

Sera from six patients (three with RA and three with FS; Table 1) were fractionated by gel filtration as follows: samples of serum $(5 \mathrm{ml})$ were centrifuged at $2000 \mathrm{~g}$ for $10 \mathrm{~min}$ and applied to a $2.5 \times 90 \mathrm{~cm}$ column of Sepharose 4B (Pharmacia Fine Chemicals, Woerden, The Netherlands). The column was eluted at $6-7 \mathrm{ml} / \mathrm{h}$ with veronal buffered saline containing $0.15 \mathrm{M} \mathrm{NaCl}$ and $2 \mathrm{mM}$ ethylenediaminetetra-acetic acid, and $5 \mathrm{ml}$ fractions were collected. The protein elution profile was assessed by measuring the optical density at $280 \mathrm{~nm}$ of the fractions, which were then combined in two pools, each of which was concentrated by ultrafiltration to the original volume of the fractionated sample and stored until use at $-20^{\circ} \mathrm{C}$. The IgG and IgM contents of the pools were measured with a sandwich enzyme linked immunosorbent assay for human immunoglobulins. ${ }^{19}$ In short, microwells were coated with rabbit IgG antihuman IgG or IgM and incubated with samples of the pools. Bound human immunoglobulins were detected by adding peroxidase conjugated rabbit IgG antihuman IgG or IgM (Dakopatts, Copenhagen, Denmark) followed by $100 \mu \mathrm{g} / \mathrm{ml} o$-phenylenediamine (Sigma Chemicals, St Louis, Mo) in $0.05 \mathrm{M}$ phosphate (pH 5.6) (Dakopatts) containing 0.02\% $\mathrm{H}_{2} \mathrm{O}_{2}$.

\section{IMMUNE COMPLEXES}

IC were precipitated by adding $3 \%$ (w/v) polyethylene glycol (PEG 6000, BDH Chemicals Ltd, Poole, England) to serum from patients with FS. PEG was dissolved in $0.1 \mathrm{M}$ boric acid, $0.025 \mathrm{M}$ disodium tetraborate, and $0.075 \mathrm{M} \mathrm{NaCl}(\mathrm{pH} \mathrm{8)}$. After mixing of the contents the tubes were left on ice for $60 \mathrm{~min}$ and then centrifuged at $2400 \mathrm{~g}$ at $4^{\circ} \mathrm{C}$ for $20 \mathrm{~min}$.

The IC content of all patient sera was measured by the $\mathrm{Clq}$ binding assay (C1qBA) $;{ }^{20}$ the amount of IC was expressed as micromoles of a standard of aggregated $\mathrm{IgG}^{21}$ Human IgG was isolated from heat inactivated donor serum by ammonium sulphate precipitation and anion exchange chromatography on diethylaminoethyl-cellulose. Aggregated human IgG was prepared by heating a solution of $10 \mathrm{~g} / \mathrm{l}$ purified human IgG at $63^{\circ} \mathrm{C}$ for 30 $\min$.

ANIMAL EXPERIMENTS

Inbred male NMRI mice (40-45 g) were injected intravenously with $200 \mu \mathrm{l}$ of one of the human sera under study. Forty microlitres of blood collected from the tail into heparinised capillaries was sampled for counting of PMN, mononuclear cells (MNC), and erythrocytes immediately before and at various intervals after the injection. Leucocyte counts were corrected for changes in erythrocyte counts. The effect of each serum was calculated as the mean of two experiments, which generally differed by less than $10 \%$. The results for each of the patient groups are presented as mean $\pm \mathrm{SD}$ of the calculated values for each of the individual sera.

STATISTICAL ANALYSIS

Statistical significances were determined by the Student's $t$ test.

\section{MICROSCOPIC STUDIES}

Tissue specimens were taken from the lungs, kidneys, spleen, and liver of animals killed $12 \mathrm{~min}$ after being injected with $200 \mu$ l serum of patients with FS. Part of each of these specimens was snap frozen for immunohistochemical evaluation and part was processed for methyl methacrylate embedding, as described elsewhere, ${ }^{22}$ for histological examination. Human immunoglobulin was detected by the indirect two step immunoperoxidase technique with the use of antisera against human IgG (Dakopatts, Denmark).

\section{Results}

EFFECT OF PATIENT SERA

The course of the leucocyte counts made after the injection of $200 \mu \mathrm{l}$ serum from FS patients into mice showed a drop for both PMN and MNC within three to six minutes after the injection (Fig. 1). The maximum decrease was found after nine to 12 minutes, the range amounting to $98-34 \%$ of the initial PMN count. Shortly after this peak, rebound granulocytosis occurred at about 21-24 minutes, whereas the number of MNC increased more gradually. Table 1 shows the C1qBA results for the patient sera and the changes in the numbers of circulating PMN 12 minutes after the injection of $200 \mu \mathrm{l}$ serum. Correlation between these parameters was not found.

After the injection of $200 \mu \mathrm{l}$ serum from RA patients without neutropenia the sera of two 
698 Breedveld, Lafeber, de Vries, van Krieken, Cats

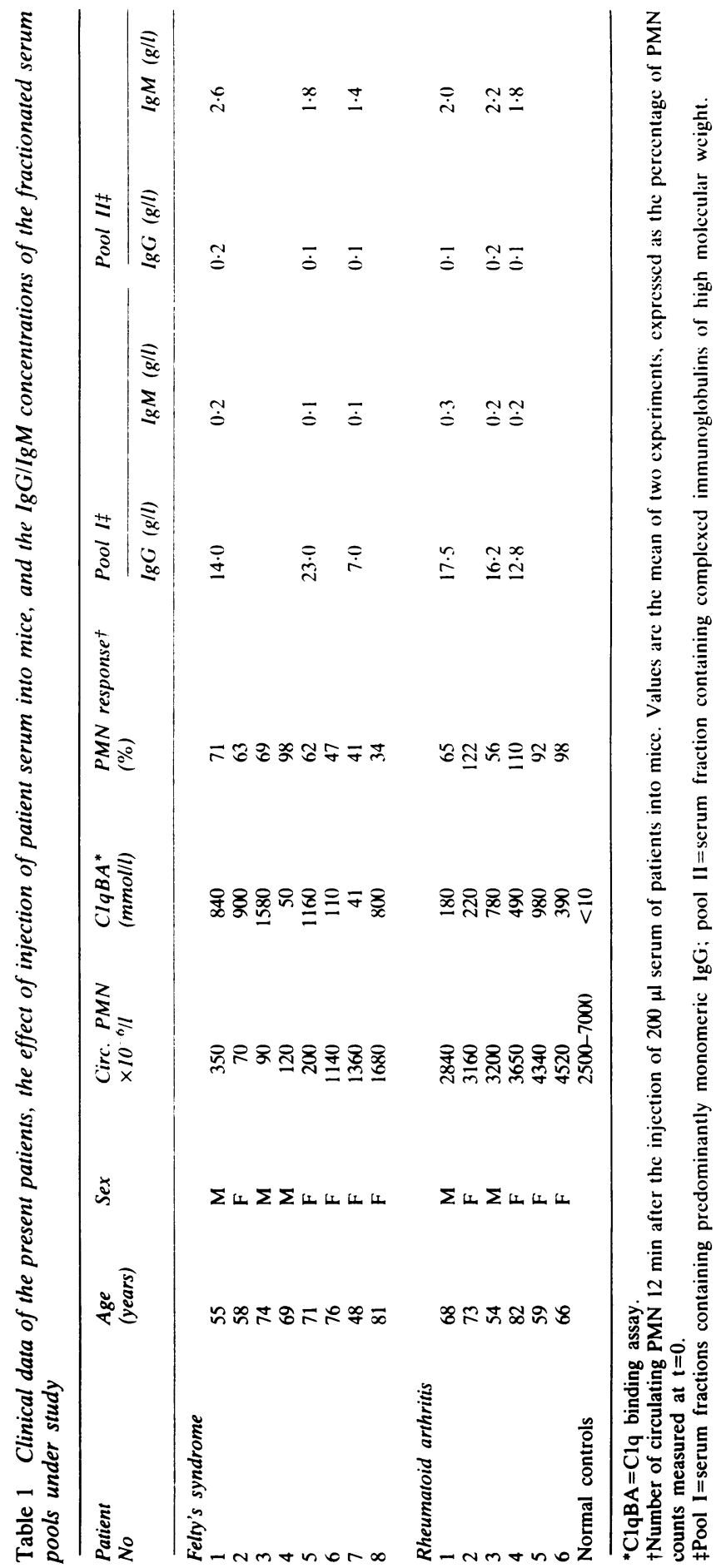



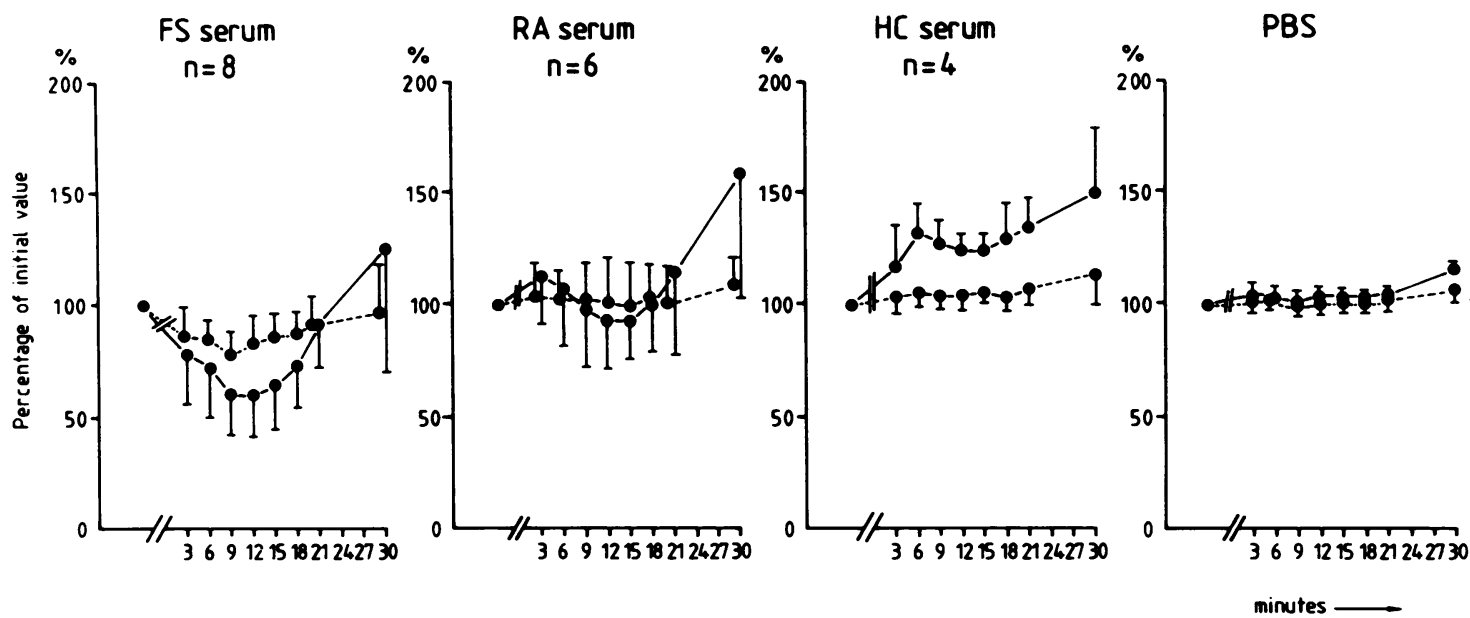

Fig. 1 Effect of intravenous injection of $200 \mu$ l serum of patients with Felty's syndrome (FS) or rheumatoid arthritis (RA), serum of healthy controls $(H C)$, and phosphate buffered saline (PBS), on the number of circulating $P M N$ (solid lines) and mononuclear cells (dashed lines) in mice. The data are expressed as percentage of leucocyte counts measured at $t=0$ and are corrected for changes in erythrocyte counts. PBS was tested in three mice. $n=$ number of human sera investigated.

patients led to a significant temporary decrease of the PMN and MNC counts and those of four patients only to a slight decrease or even an immediate increase (Fig. 1, Table 1). The difference between the maximum effect of FS and RA sera on the number of circulating PMN was statistically significant $(p=0 \cdot 03)$. Mice injected with $200 \mu \mathrm{l} \mathrm{HC}$ serum always showed an immediate increase in the number of both circulating PMN and MNC (Fig. 1). Leucocyte counts did not change significantly after the injection of $200 \mu \mathrm{l}$ phosphate buffered saline (PBS, Fig. 1).

Increased vascular permeability, as judged from a rise of the erythrocyte counts, was not found for PBS or HC serum but was present nine minutes after injection of FS serum or heat aggregated IgG (AIgG) (Table 2).

Table 2 Course of erythrocyte counts determined at various intervals after the injection into mice of $200 \mu \mathrm{l}$ $P B S$, healthy control serum, serum of patients with Felty's syndrome, or $1 \mathrm{~g} / \mathrm{l}$ heat aggregated $\mathrm{IgG}$

\begin{tabular}{cllll}
\hline $\begin{array}{l}\text { Time } \\
(\text { min })\end{array}$ & PBSt & $\begin{array}{l}\text { HC serum } \\
(n=4)\end{array}$ & $\begin{array}{l}\text { FS serum } \\
(n=8)\end{array}$ & AlgGt \\
\hline 0 & 100 & 100 & 100 & 100 \\
9 & $96 \cdot 3 \pm 1 \cdot 5$ & $89 \cdot 3 \pm 4 \cdot 5$ & $106 \cdot 8 \pm 5 \cdot 2$ & $111 \cdot 2 \pm 10 \cdot 6$ \\
21 & $90 \cdot 6 \pm 2 \cdot 1$ & $87 \cdot 0 \pm 1 \cdot 0$ & $98 \cdot 6 \pm 4 \cdot 7$ & $105 \cdot 0 \pm 9 \cdot 8$ \\
30 & $87 \cdot 3 \pm 4 \cdot 7$ & $87 \cdot 6 \pm 4 \cdot 0$ & $94 \cdot 0 \pm 6 \cdot 4$ & $96 \cdot 5 \pm 6 \cdot 0$ \\
\hline
\end{tabular}

*Data were expressed as the percentage of erythrocyte counts measured at $\mathbf{t}=0$. $n=$ number of human sera investigated. †PBS and AIgG were tested in three mice each.
EFFECT OF IMMUNE COMPLEXES IN PATIENT S ERA

The role of IC in the effect of FS serum in mice was investigated by PEG precipitation of the IC present in the sera of FS patients. The number of circulating PMN decreased at most to a mean of $60 \%$ of the initial PMN count after injection of untreated patient serum, whereas PMN counts did not drop after injection of sera treated with PEG (Fig. 2A). The number of circulating MNC decreased on average by $10 \%$ with non-treated sera and only increased with PEG treated sera (data not shown). In control experiments the effect of the injection of donor serum or PBS on the number of leucocytes was the same before and after PEG treatment of both (data not shown).

To find out whether the effect of IC on the number of circulating leucocytes is dose dependent we performed experiments with serial dilutions of heat aggregated human IgG. The results showed a decrease in the number of PMN and MNC dependent on concentration. Injection of $200 \mu \mathrm{l} \mathrm{AIgG}$ at concentrations higher than $1 \mathrm{mg} / \mathrm{ml}$ led to death of the animal within five to 10 minutes. Similar concentrations of unaggregated IgG did not induce a decrease in the number of circulating PMN or MNC (see Fig. 2B for the PMN counts).

To find out whether the differences in the effect of sera from FS and RA patients on the number of circulating leucocytes could be attributed to differences in the concentrations of aggregated immunoglobulins in these sera we studied the effect of serum 
fractions obtained by Sepharose 4B gel filtration. The serum fractions predominantly containing monomeric IgG and those containing complexed immunoglobulins of high molecular weight were pooled (pool I and pool II respectively). After the pools were concentrated to approximately $5 \mathrm{ml}$ the IgG and IgM concentrations were determined (Table 1). Differences in the concentrations of IgG and IgM in pool II of the patients with FS or RA were small. The injection of $200 \mu \mathrm{l}$ of the $7 \mathrm{~S}$ material (pool I) produced an increase in the number of circulating PMN and MNC in all samples tested. The injection of $200 \mu \mathrm{l}$ of material containing complexed immunoglobulins (pool II) was followed by a distinct decrease of PMN and MNC counts with $\overrightarrow{\vec{D}}$ the three FS serum pools tested and a less pronounced decrease of the leucocyte counts with only two of the three RA serum pools (see Fig. 3 for the PMN counts).

LIGHT MICROSCOPY AND

IMMUNOHISTOCHEMICAL EVALUATION Light microscopical sections of lung, kidney, spleen, and liver tissue from mice injected with $200 \mu \mathrm{l}$ serum $\vec{\omega}$ from patients with FS showed increased sequestration of PMN and MNC in the vascular bed and

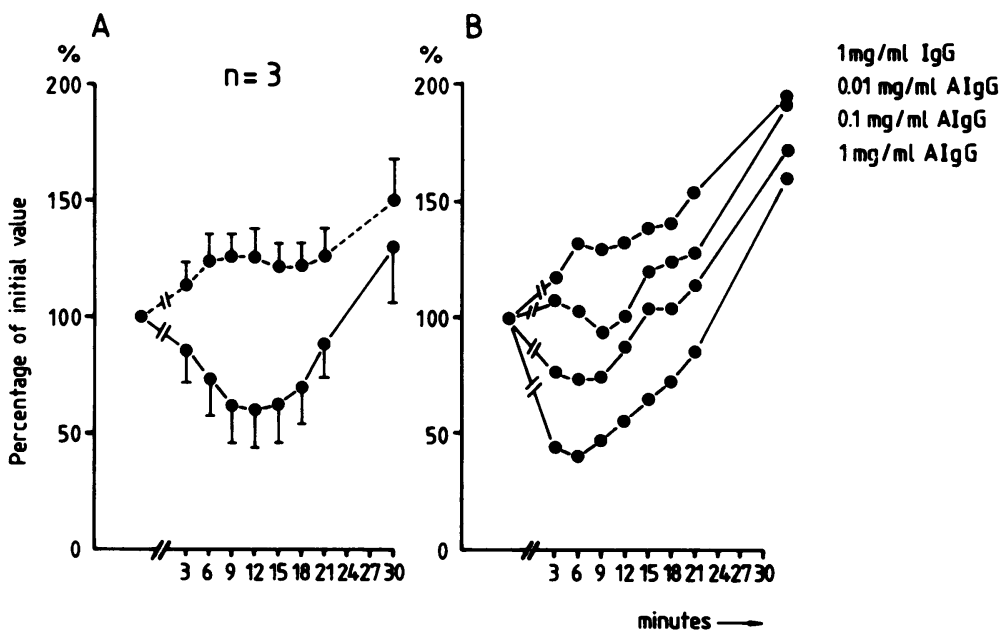

Fig. 2 Effect of intravenous injections on the number of circulating PMN in mice. The data are expressed as percentage of leucocyte counts measured at $t=0$ after correction for erythrocyte counts. (A) Effect of injection of $200 \mu$ l serum of patients with Felty's syndrome, before (solid lines) and after (dashed lines) incubation of the sera with PEG. $n=$ number of patients investigated. (B) Effect of injection of $200 \mu \mathrm{l}$ of serial dilutions of a solution of $1 \mathrm{mg} / \mathrm{ml}(\mathrm{g} / \mathrm{l})$ heat aggregated $\mathrm{IgG}$ (AIgG) and the effect of $1 \mathrm{mg} / \mathrm{ml}$ IgG. Each solution was tested in three mice.

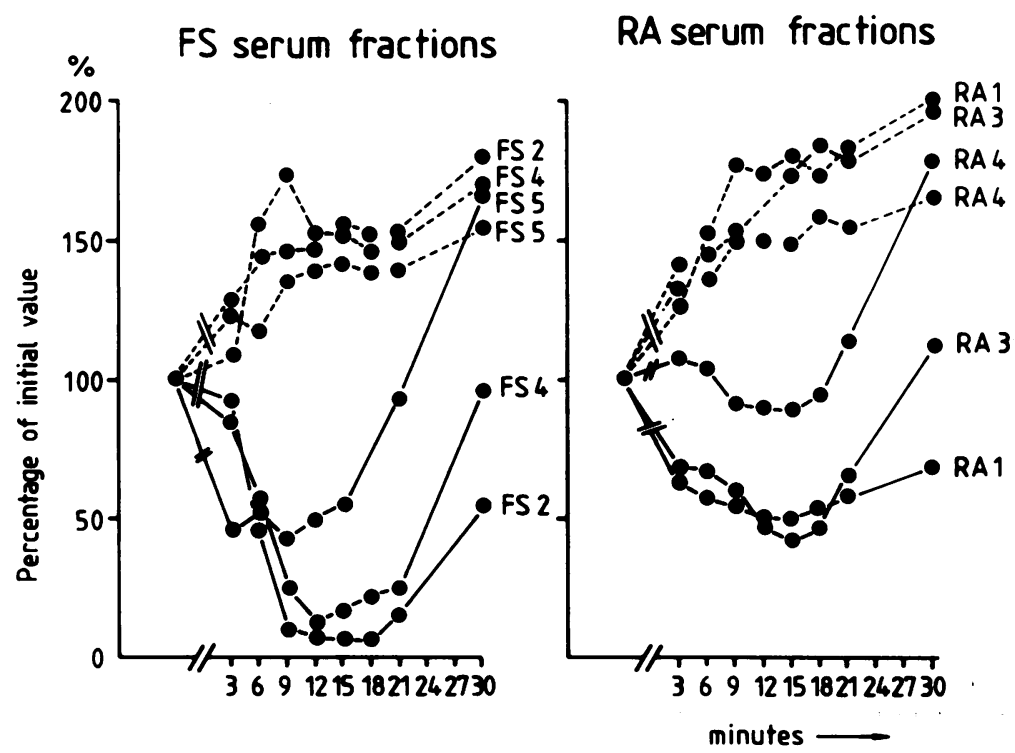

Fig. 3 Effect on the number of circulating PMN in mice of intravenous injection of $200 \mu \mathrm{l}$ serum-pool I (dashed lines), pool II (solid lines)-obtained by Sepharose $4 B$ gel filtration of serum of patients with Felty's syndrome (FS) and rheumatoid arthritis $(R A)$. The pools were made from serum fractions containing monomeric immunoglobulins (pool I) and serum fractions containing immunoglobulins in fractions with higher molecular weight (pool II). 
interstitium of the lungs compared with mice injected with PBS. Other organs did not show an increased number of leucocytes after the injection of patient serum.

Immunohistochemical studies showed the presence of human $\operatorname{IgG}, \operatorname{IgA}$, and IgM in the lung tissue of mice injected with patient serum, especially at places with aggregations of PMN. Negative results were obtained in mice injected with PBS.

\section{Discussion}

The present results show that serum from patients with FS and some patients with RA can induce leucopenia (primarily neutropenia) when injected into mice. Leucocyte sequestration was found in the vascular bed of the lungs. Evidence is provided that this leucopenia is caused by IC present in these sera.

Administration of soluble IC to small rodents provides a relatively simple basis for assessment of the effects of circulating IC on the kinetics of leucocytes. The use of heterologous immunoglobulins is an acceptable model because there is known to be a high degree of cross reactivity in binding between complexed human IgG and animal leucocytes. ${ }^{172324} \mathrm{~A}$ fall in the number of circulating PMN and leucocyte aggregation in pulmonary vessels after intravenous administration of IC in animals, as found in the present study, has already been described in reports of early studies on anaphylaxis. ${ }^{25} 26$ The mechanisms underlying this effect of IC on PMN in animals have been studied by several authors. Neutropenia follows intravascular PMN aggregation and increased adherence of PMN to endothelial cells. ${ }^{27} 28$ This increased adherence has been related to receptor mediated binding of IC to PMN and to complement activation, including C5a anaphylatoxin generation. ${ }^{18} 29-31$ The latter may induce release of mediators by PMN and changes in the composition of glycoproteins in the PMN membrane that increase PMN adhesiveness. ${ }^{18}$ 32-35

Serum fractions from FS patients that contained IC were more active in producing leucopenia than corresponding fractions from RA patients. This difference may be due to differences in the concentration of IC since a concentration dependent decrease in the number of PMN was found after injection of serial dilutions of AIgG, but this is not supported by the absence of correlation between the leucokinetic effect of the patient sera and either the C1qBA results or the immunoglobulin concentrations of the serum fractions tested. Differences in the size of IC in sera, such as have been found between patients with FS and RA, ${ }^{36}$ might be an alternative explanation, but the composition and the electric charge of the IC and their ability to activate complement and to bind to PMN may also be of influence. Further work is needed to clarify this point.

Neutropenia has been thought to be caused by circulating IC in cases of chronic idiopathic neutropenia ${ }^{37}$ and SLE. ${ }^{38}$ In vitro studies have shown that serum from patients with FS can induce PMN aggregation and increased adherence of PMN to endothelial cells. ${ }^{39}$ Moreover, Calabresi et al saw a transient neutropenia develop in healthy volunteers immediately after injection of serum from two FS patients, ${ }^{40}$ and this pattern was similar to that of the PMN kinetics in mice observed in the present study, which suggests that in man, too, this effect of FS serum was due to IC.

There is thus evidence supporting the concept that the interaction between PMN and IC in the peripheral blood depresses PMN counts in experimental and human immune complex disease. Whether neutropenia develops in RA patients with circulating IC may depend on the granulopoietic activity in the bone marrow, the size of the spleen, and the amount and type of the IC. The results of this study show that in patients with FS circulating IC have a specific potential for the induction of peripheral sequestration of PMN in mice. This, in combination with the fact that most FS patients have high levels of circulating $\mathrm{IC}^{3641}$ and neutropenia due to a shift of PMN from a circulating to a marginated pool, ${ }^{5}$ seems to suggest that the persistent in vivo interaction between IC and PMN in FS has a previously neglected role in the pathogenesis of the disease.

\section{References}

1 Felty A R. Chronic arthritis in the adult associated with splenomegaly and leukopenia. Bull Hopkins Hosp 1924: 35: 16-20.

2 Gupta R, Robinson W A, Albrechts D. Granulopoietic activity in Felty's syndrome. Ann Rheum Dis 1975; 34: 156-61.

3 Abdou N I. Heterogeneity of bone marrow-directed immune mechanisms in the pathogenesis of neutropenia in Felty's syndrome. Arthritis Rheum 1983; 26: 947-53.

4 Bishop C R, Rothstein G, Ashenbrucher H E, Athens J W. Leukokinetic studies XIV. Blood neutrophil kinetics in chronic, steady state neutropenia. J Clin Invest 1971; 50: 1678-89.

5 Vincent P C, Levi J A, MacQueen A. The mechanism of neutropenia in Felty's syndrome. Br J Haematol 1974; 27: 463-75.

6 Joyce R A, Boggs D R, Chervenick P A, Lalezari P. Neutrophil kinetics in Felty's syndrome. Am J Med 1980; 69: 695-702.

7 Dausset J. Auto-antileukocyte ribosomal fraction in leukoneutropenias. Ann NY Acad Sci 1965; 124: 550-62.

8 Faber V, Elling E. Leukocyte-specific antinuclear factor in patients with Felty's syndrome, rheumatoid arthritis, systemic lupus erythematosus and other diseases. Acta Med Scand 1966; 179: $257-67$. 
9 Rosenthal F D, Beeley J M, Gelsthorpe K, Doughty R W. White-cell antibodies and the aetiology of Felty's syndrome. $Q J$ Med 1974; 43: 187-93.

10 Starkebaum G, Singer J W, Arend W P. Humoral and cellular immune mechanisms of neutropenia in patients with Felty's syndrome. Clin Exp Immunol 1980; 39: 307-14.

11 Logue G L, Huang A F, Skimm D W. The role of antibodies supporting granulocyte lysis by lymphocytes. $N$ Engl $J$ Med 1981; 304: 580-3.

12 Cines D B, Passero F, Guerry D, Bina M, Dusak B, Schreibner A D. Granulocyte associated IgG in neutropenic disorders. Blood 1982; 59: 124-32.

13 Starkebaum G, Arend W P, Nardella F A, Gavin S E. Characterization of immune complexes and immunoglobulin $G$ antibodies reactive with neutrophils in the sera of patients with Felty's syndrome. J Lab Clin Med 1980; 96: 238-51.

14 Petersen J, Wiik A. Lack of evidence for granulocyte specific membrane-directed auto-antibodies in neutropenic cases of rheumatoid arthritis and auto-immune neutropenia. Acta Pathol Microbiol Immunol Scand [C] 1983; 91: 15-22.

15 Breedveld F C, Lafeber G J M, De Vries E, Leyh P C J, Daha $M R$, Cats A. Fc receptors on granulocytes from patients with rheumatoid arthritis and Felty's syndrome. Clin Exp Immunol 1984; 55: 677-83.

16 Breedveld F C, Lafeber G J M, Doekes G, Claas F, Cats A. Felty's syndrome: autoimmune neutropenia or immune complex mediated disease? Rheumatol Int 1986; 5: 253-8.

17 Movat H Z, Uriuhara T, Tachman N S, Rovsell H C, Mustard $J$ F. The role of PMN-leukocyte lysosomes in tissue injury, inflammation and hypersensitivity IV. The participation of the PMN-leukocyte and the blood platelet in systemic anaphylaxis. Immunology 1968; 14: 637-48.

18 Camussi G, Tetta C, Bussolino F, et al. Mediators of immune complex induced aggregation of polymorphonuclear neutrophils II. Platelet-activating factor as the effector substance of immune-induced aggregation. Int Arch Allergy Appl Immunol 1981; 64: 25-31.

19 Voller A, Bidwell D E, Barlett A. Enzyme immunoassays in diagnostic medicine. Bull WHO 1970; 53: 3418-24.

20 Zubler R A, Nydegger N E, Persin L H, et al. Circulatıng and intra-articular immune complexes in patients with rheumatoid arthritis. J Clin Invest 1976; 57: 1308-19.

21 Kauffmann R H, Van Es L A, Daha M R. Aggregated human immunoglobulin $G$ stabilized by albumin: a standard for immune complex detection. J Immunol Methods 1979; 31: 11-22.

22 Te Velde J, Burkhardt R, Kleiverda K, Leenheers-Binendijk L, Sommerfeld W. Methyl-methacrylate as an embedding medium in histopathology. Histopathology 1977; 1: 319-30.

23 Jiminez R A H, Haakenstad A O, Mannik M. Hepatic uptake of small-latticed immune complexes does not alter mononuclear phagocyte system function. Immunology 1983; 48: 205-10.

24 Camussi G, Bussolino F, Tetta C, et al. Effect of prostacyclin $\left(\mathrm{PGI}_{2}\right.$ ) on immune complex-induced neutropenia. Immunology 1983; 48: 625-33.

25 Dragstedt C A, Arellano M E, Lawton A H, Smith P H. Passive sensitization of rabbit's blood. J Immunol 1940; 39: 537-42.
26 Rose B, Browne J S L. Studies on the release of histamine from the blood cells of the rabbit by addition of horse serum or egg albumin in vitro. $J$ Immunol 1941; 41: 403-9.

27 Henson P M. The adherence of leukocytes and platelets induced by fixed IgG antibody or complement. Immunology 1969; 16: 170-4.

28 Hashimoto Y, Hurd E R. Human neutrophil aggregation and increased adherence to human endothelial cells induced by heat aggregated IgG and immune complexes. Clin Exp Immunol 1981; 44: 538-47.

29 Lay W H, Nussenzweig V. Receptor for complement on leukocytes. J Exp Med 1968; 128: 99-105.

30 Camussi G, Mencia-Huerta J M, Benveniste J. Release of platelet-activating factor and histamine I. Effect of immune complexes, complement and neutrophils on human and rabbit mastocytes and basophils. Immunology 1977; 33: 523-9.

31 Jacob H S, Craddock P R, Hammerschmidt D E, Meldow C F. Complement-induced granulocyte aggregation. $N$ Engl J Med 1980; 302: 789-91.

32 Olsson T, Venge P. Cationic proteins of human granulocytes. Isolation of the cationic proteins from the granules of leukemic myeloid cells. Scand J Hematol 1972; 9: 204-7.

33 Oseas R, Yang H H, Bachner R L, Boxer L A. Lactoferrin: a promoter of polymorphonuclear leukocyte adhesiveness. Blood 1981; 57: 939-45.

34 Boxer L A, Björksten B, Björk J, Yang $\mathbf{H ~ H}$, Allen $\mathbf{J} \mathbf{M}$, Bachner $\mathbf{R}$ L. Neutropenia induced by systemic infusion of lactoferrin. J Lab Clin Med 1982; 99: 866-72.

35 Todd R F, Arnaout M A, Rosin R E, Crowley C A, Peters W A, Babior B M. Subcellular localization of the large subunit of $\mathrm{Mol}\left(\mathrm{Mol}_{\alpha}\right.$; formerly $\left.\mathrm{gp} 10\right)$, a surface glycoprotein associated with neutrophil adhesion. J Clin Invest 1984; 74: $1280-90$.

36 Hurd E R, Chubick A, Jasin H E, Ziff M. Increased C1q binding immune complexes in Felty's syndrome. Arthritis Rheum 1979; 22: 697-702.

37 Caligaris-Cappio F, Camussi C, Gavesto F. Idiopathic neutropenia with normocellular bone marrow: an immune complex disease. Br J Haematol 1979; 43: 595-605.

38 Camussi G, Segoloni G, Stratta $P$, et al. In vivo fixation of immune complexes on polymorphonuclear cells and release of neutrophil cationic proteins in systemic lupus erythematosus. Dialysis transplantation nephrology: Proceedings of the 14th Congress of the European Dialysis Transplant Association 1977: 478-85.

39 Hashimoto Y, Ziff M, Hurd E. Increased endothelial cell adherence, aggregation, and superoxide generation by neutrophils incubated in systemic lupus erythematosus and Felty's syndrome sera. Arthritis Rheum 1982; 25: 1409-18.

40 Calabresi P, Edwards E, Schilling R F. Fluorescent antiglobulin studies in leukopenic and related disorders. J Clin Invest 1959; 38: 2091-100.

41 Andreis M, Hurd E R, Lospalluto J, Ziff M. Comparison of the presence of immune complexes in Felty's syndrome and rheumatoid arthritis. Arthritis Rheum 1978; 21: 310-5. 